\title{
The Changing Role of the Central Planning Offices in Latin America
}

\author{
Luis Bernardo Mejia Guinand ${ }^{1}$
}

Published online: 24 June 2015

C The Author(s) 2015. This article is published with open access at Springerlink.com

\begin{abstract}
The central planning agencies in Latin America have undergone multiple transformations in their structural design. These agencies came to life during the late 1950 s in response to a development strategy that required the state to provide long-run direction to development by means of economic planning. Five decades later, the same agencies were redeployed to perform an open-market development strategy. What explains the fact that the same agency, created with the purpose of planning economic development, has functioned across time and governments with sharp economic, and political differences? Following Mahoney and Thelen (2010), this paper highlights the idea that the basic properties of institutions provide some forceful elements that permit change. In this sense, the document shows how veto possibilities and compliance are key variables in understanding the changing role of the central planning offices in Latin America.
\end{abstract}

Keywords Organizational change · Gradual transformation · Conversion · Central planning agency

\section{Introduction}

Over the past 60 years, planning agencies in Latin America have undergone multiple transformations in their structural design. In all countries, the planning body came to life during the late-1950s in response to an inward development strategy that required the state to provide long-run direction to economic development by means of economic planning. Three decades later, the same agencies were redeployed to serve the purposes of an entirely different development strategy, performing functions suitable of a freemarket development model. Subsequently, Latin American countries started to

Luis Bernardo Mejia Guinand

luimejia@uniandes.edu.co

1 Political Science Department, Universidad de los Andes, Carrera Primera \# 18A-12, Bogotá,

Colombia 
experience a rebirth of the state's economic presence around 2000, including a new reshaping of the economic planning agencies. In between these three distinct strategies for economic and social development, the planning agencies were continuously assigned and redirected toward a wide range of functions as seen necessary. What explains the fact that the same agency, created with the function of planning economic development, has served across time and governments with sometimes sharp ideological, economical, and political differences? What characteristics does this agency entail and which is its appeal allowing it to persist for such a long period of time?

This paper, analyzes the major institutional variables and actors that have influenced the changing role of Latin American central planning agencies during the last 60 years. Following Mahoney and Thelen (2010), the study highlights that the intrinsic properties of the planning organization provide some dynamic elements that permit transformation. In particular, the research calls attention to forms of institutional change linked to two variables: veto possibilities and compliance. This paper shows how the weak veto possibilities faced by those attempting to change the planning agency, combined with high levels of interpretation and low enforcement of the organizations' mandates, has permitted a conversion mode of gradual and transformative organizational change, with the President singled out as the main driver of transformation.

The empirical evidence used in this research is based on in-depth field work, especially elite interviews with former directors and ministers of domestic planning organizations, as well as the analysis of policy documents, organizational records, legal instruments and press archives.

The paper is structured in six further parts. Section 2 provides the historical background and characterization of the central planning agencies in Latin America and briefly lays out the multiple transformations across time, in the structural design of the central planning agencies. Part 3, based on Mahoney and Thelen's conceptual tools that capture the logic of endogenous and gradual organizational change, emphasizes the importance of the interaction between the political context and the characteristics of the organization as a key factor for explaining organizational gradual change. Section 4 lays out empirical evidence on the veto variable, illustrating how Latin American Presidents do not need to navigate through a large number of veto points when they wish to reorganize their administrative bureaus. Section 5, digs into the compliance variable, showing how the central planning agency was enacted through vague statutes, leaving many details unspecified and thus opening the door to high levels of discretion and interpretation in formulating development policies. Part 6 elaborates on the research's core finding. Empirical evidence show that the institutional trajectory and transformations followed by the planning bodies under research is best explained by what Thelen describes as a conversion mode of institutional change. The last part concludes.

\section{The Variation of the Structural Arrangement of the Central Planning Agencies in Latin America}

After the great depression of 1929, comprehensive development planning became accepted as means for accelerating the rate of economic growth, and breaking down structural obstacles that hindered progress. According to the Economic Commission for 
Latin America (ECLA), government's principal task was to provide long-run direction to economic development by means of economic planning. One of ECLA's main recommendations was the adoption of a long-term development policy in the region, along with the creation or strengthening of central planning agencies (Iglesias 2006; Leiva 2010).

This idea was reinforced in 1961 when President Kennedy proposed a 10-year plan for Latin America, known as Alliance for Progress (García Bossio 2008; Leiva 2010). The program called for an annual increase of $2.5 \%$ in per capita income, the elimination of adult illiteracy, the establishment of a land reform agenda and the adoption of economic and social planning (Taffet 2007). Participating countries were to design comprehensive plans for national development as a prerequisite for receiving economic aid.

Almost all Latin American governments embraced planning as an instrument for bringing about necessary structural changes, but most importantly as a tool for mobilizing national resources and qualifying for international aid under the Alliance for Progress. In support of this effort, ECLA created the Latin American Institute for Economic and Social Planning (ILPES) in 1962, with the purpose of supporting the Latin American Governments in the area of planning through the provision of training, advisory and research services (ILPES 2013).

Since its inception, ILPES advocated for the establishment of central planning offices (Waterston 1966). Those Latin American countries that had not yet established their central planning agencies during the 1950 s created them throughout the $1960 \mathrm{~s}$, while other countries strengthened their existing ones.

There was a notable variety in the structural arrangement of the agencies. Uruguay, Honduras, Guatemala, El Salvador, Ecuador, Dominican Republic, Cuba and Argentina adopted a collegial body (commission, board or council) as the organizational form for their planning offices. The collegial body consisted of five to seven members, who tended to represent several of the economic-related ministries. Commissioners were appointed by the President and the functions of the organization were normally advisory in nature. In Chile, Costa Rica, Panamá, Trinidad and Tobago, Venezuela and Nicaragua, the planning agency was an administrative unit within the internal organization of the executive office of the President. In Brazil, Colombia, Mexico and Paraguay, the planning office took the form of a ministry, whereby the minister of planning was appointed by the President and had responsibility for one or more agencies or other administrative organizations. In Barbados, the planning body was located as an administrative unit within the internal organization of the Finance ministry. Finally, Bolivia, Haiti, Jamaica and Peru developed their central planning office as an administrative agency.

Regardless of the specific structure given to central planning offices, whether a collegial body or ministry, the different countries shared a view of the planning agency as a central organization meant to work across government departments or ministries to provide advice to the President on economic development, as well as ensuring policy coherence and coordination on his behalf. The central planning agencies had either formal or informal authority over other departments, ministries and administrative agencies.

During the early-1980s, the import-substitution industrialization model in Latin America was reaching its limits. "Not only the size of Latin American domestic markets constrained the opportunities for further industrialization, but also the 
accumulation of distortions associated with the panoply of government interventions imposed a growing drag on the growth prospects of these economies"(Primo Braga 2006: 4). This so-called lost decade was characterized by massive foreign debt and macroeconomic problems (especially inflation and fiscal deficit) that occurred during the transition to democracy.

In face of the aforementioned situation, some countries withdrew executive economic functions from the central planning agencies, transferring them to the ministry of finance, while other countries favored short-term economic measures led by their planning offices.

Following the Chilean experience, a number of Latin American governments implemented measures to control the fiscal deficit, including tax reforms, the liberalization of trade, financial markets, interest and exchange rates and the reduction of the state's size and role. ${ }^{1}$ While the central planning agencies were the natural candidates to disappear in this context of pro-market and multilevel planning public sector reforms, they persisted in the region, with few exceptions. Mexico turned off its Secretariat of Programming and Budget in 1992, transferring many of its functions to the Secretariat of Finance. Peru deactivated its central planning office in 1992 under the state modernization reforms followed by the Fujimori's government, while Honduras disengaged its office (SECPLAN) in 1996. Finally, Panama merged the Ministry of Planning with the Ministry of Finance in 1998, creating the Ministry of Economy and Finance.

With the adoption of neo-liberal policies, some of the functions that central planning offices had been performing were strengthened, while new administrative reorganizations took place. Capabilities for project appraisal and the prioritization of public investment were now reinforced as a requirement for the implementation of structural adjustment programs. At the same time, tasks related to negotiating international cooperation and, to a lesser extent, dealing with the public sector restructuring, started to appear as a mandate of the planning agencies.

Throughout the 2000s, Latin American governments that had favored pro market policies, started to be replaced by administrations leaning to the left (Cameron 2009). Candidates from the left emerged triumphant in Argentina, Bolivia, Brazil, Chile, Ecuador, Guatemala, Honduras, Nicaragua, Paraguay, Uruguay and Venezuela. However, regardless of the ideological affiliation, Latin American governments began bringing the planning agencies back. This trend responded to attempts to better integrate the planning process with the budgetary process, or to an effort to exercise the government's greater intervention in the economy. In this context, Peru reactivated its central planning agency in 2005 with the creation of the National Strategic Planning Center (CEPLAN). In 2004, Ecuador transformed the old Planning Office (ODEPLAN) into the National Planning and Development Secretariat (SENPLADES), assigning it a predominant role in the budgetary process. Bolivia restructured the Ministry of Sustainable Development into the Ministry of Development Planning in 2006, with the task of being the main governing body of the National Planning and Public Investment Systems. Argentina reorganized its Planning Secretariat into the Ministry of Federal Planning, Investment and Public Services, assigning it regulatory functions in transport, mining, communication and energy policies.

\footnotetext{
${ }^{1}$ Venezuela 1989-1994; Mexico 1988-1994; Bolivia 1985-1989; Argentina 1989-1999; Peru 1990-2000; Nicaragua 1990-1997; Brazil 1990-1994; Colombia 1991-1994.
} 
Unlike the 1960s, when there was a wide variety of organizational arrangements among the planning offices, today there is greater homogeneity. Argentina, Bolivia, Brazil, Chile, Colombia, Costa Rica, Cuba, Dominican Republic, Haiti, Uruguay and Venezuela have adopted the figure of ministry as the preferred structural arrangement for the planning office, while four nations Ecuador, Guatemala, Paraguay and Uruguay have created their planning agencies as a technical entity under the Presidency of the Republic and two, Nicaragua and Peru, have arranged their central planning agency as a collegial advisory body. These figures indicate that planning entities in Latin America over the past 15 years, have concentrated further under direct influence of the President.

\section{Explaining Endogenous Change}

Mahoney and Thelen (2010) highlight the idea that the basic properties of institutions provide some forceful elements that permit change. Particularly, veto possibilities and compliance are key variables in understanding organizational change.

The first variable, veto possibilities, is understood as the role of individual or collective actors whose agreement is necessary to change the status quo (Tsebelis 2002). Tsebelis (2002) focuses on the effective number of institutional veto points, in the sense that it is more difficult to change policy the more veto points in a system, because the probability of a player exercising its veto option increases with numbers. Whether veto players or veto points, "veto possibilities are high where there exist actors who have access to institutional or extra-institutional means of blocking change" (Mahoney and Thelen 2010: 19).

The second variable, compliance, refers to the need to enforce the institution. Following Mahoney and Thelen (2010), the urgency to put institutions into effect not only emerge from the politically contested nature of institutional rules, but also from a degree of openness in the interpretation and implementation of these rules. "Even when institutions are formally codified, their guiding expectations often remain ambiguous and always are subject to interpretation, debate, and contestation" (Mahoney and Thelen 2010: 11)

The confluence of low veto possibilities against those trying to change the status quo with high levels of discretion in the compliance, interpretation and enforcement, of the institution's mandates provide the setting in which it is more likely for a conversion mode of organizational change to occur.

Conversion refers to the fact that institutions are strategically redirected to new goals, functions or purposes. Here, the rules remain formally the same yet are interpreted and enacted in new ways (Thelen 1999, 2003, 2009). Such redeployment might occur as a consequence of new environmental challenges, to which policymakers respond by directing existing institutional resources to new ends. Alternatively, "it can come about through changes in power relations, such that actors who were not involved in the original design of an institution take it over and turn it to new ends" (Streeck and Thelen 2005: 38). The next sections build upon these insights by showing how these two variables, veto and compliance may contribute to understanding the changing role of the central planning offices in Latin America. 


\section{The Role of Veto in the Changing Character of the Central Planning Agencies}

According to Tsebelis (2002), one institutional feature of Latin American constitutions has remained unchanged since their establishment 200 years ago: the President's formal power to introduce legislation on a broad range of policy areas and compel congressional action. These constitutional powers of the President allow him to initiate major policy change, or to prevent it from happening (Rius and van de Walle 2003).

The President's faculties that have been most frequently stressed are his veto authority and decree power. Veto power refers to the situation in which no bill can become law without meeting the President's approval (Mainwaring and Shugart 1997). After legislation is passed by the legislative and signed into law by the executive, the President implements the law via regulatory decrees, whereby detailed rules are attached to the more general provisions of the legislation (Sondrol 2005). On the other hand, decree power means that the Presidents are allowed to legislate, without Congress, by means of a different kind of executive mandates such as decree-laws and regulatory directives (Tsebelis and Aleman 2005).

According to Mainwaring and Shugart (1997), veto power is essentially reactive because it allows the President to defend himself from the attempts of the legislative to alter the state of affairs through passing a new legislation. By contrast, decree power is proactive, given that it enables the President to initiate legislation submitted to Congress, in this way establishing a new status quo (Bonvecchi and Scartascini 2011).

In addition to veto and decree powers, the President in almost all countries of the region, has the authority to set the policy agenda through mechanisms such as prioritizing bills, enacting urgency decrees and calling plebiscite or referendum. Finally, Latin American Presidents also have the right to initiate legislation on a broad range of policy areas, including the budget and the reorganization of the public administration.

The power to maintain or reorganize the administrative apparatus enables Latin American Presidents not only to centralize control of decision making in the Presidency, but also to pursue public policy without Congress. According to Mainwaring, "when Presidents are incapable of pushing critical legislation through Congress, they often create new state agencies as a means of enhancing their power and accomplishing their agendas" (Mainwaring 1990: 169). A reformist agenda may move faster and further if Presidents find themselves in an office with significant constitutional legislative prerogatives (decree power, veto power, exclusive right of legislative introduction).

The tendency to pursue administrative reforms in Latin America through the executive rather than through Congress is present in the context of the planning agencies. Table 1 shows the rule of law that enacted the planning body in sixteen Latin American countries, during the late-1950s and early-1960s. Twelve out of sixteen countries (Argentina, Bolivia, Brazil, Ecuador, Guatemala, Nicaragua, Panama, Paraguay, Peru, Uruguay and Venezuela) created their central planning organization through a rule of law issued by the head of state (Decree, Decree Law, Presidential Agreement, etc.). The remaining four countries (Chile, Colombia, Costa Rica and Dominican Republic) enacted their planning body through Congress-approved Law. However, in 
Table 1 Legal instrument behind the creation of the planning office

\begin{tabular}{|c|c|c|c|}
\hline Country & Planning body & Rule of law & Year \\
\hline Argentina & Consejo Nacional de Desarrollo & Decree 7.290 & 1961 \\
\hline Bolivia & Junta Nacional de Planeamiento & Sup. Decree $N^{\circ} 5600$ & 1960 \\
\hline Brazil & Ministério de Planejamento & Delegated law No. 1 & 1962 \\
\hline Chile & Oficina de Planificación Nacional & Law $\mathrm{N}^{\circ} 16.635$ & 1967 \\
\hline Colombia & Departamento Adm. de Planeación & Law 19 & 1958 \\
\hline Costa Rica & Oficina de Planif. de la Presidencia & Law $N^{\circ} 3087$ & 1963 \\
\hline D. Republic & Junta Nac. de Planificación & Law 5788 & 1962 \\
\hline Ecuador & Junta Nacional de Planificación & Emerg. Decree Law Nº 19 & 1954 \\
\hline Guatemala & Consejo Nacional de Planificación & Decree Law 114 & 1954 \\
\hline Mexico & Comis. Intersec. Para la Planific. & Presidential Agreement & 1962 \\
\hline Nicaragua & Ofic. de Planificación Económica & Decree 52 & 1962 \\
\hline Panama & Dirección General de Planificación & Decree Law 11 & 1961 \\
\hline Paraguay & Secretaria Técnica de Planificación & Decree - Law No 312 & 1962 \\
\hline Peru & Instituto Nacional de Planificación & Decree Law No 14220 & 1962 \\
\hline Uruguay & Com. de Inv. y Desarrollo Económico & Executive power & 1960 \\
\hline Venezuela & Oficina Central de Planificación & Decree $\mathbf{N}^{\circ} \mathbf{2 8 7}$ & 1958 \\
\hline
\end{tabular}

Source: constructed by the author, 2014

these four cases it was the President (executive) who initiated the legislation, submitting the draft bill to Congress.

The authority of Latin American Presidents to create, transform and terminate administrative agencies has not significantly changed since the onset of the planning offices. Table 2 shows the rule of law of the latest administrative reorganization of the planning body in fifteen Latin American countries. Here, nine countries (Argentina, Brazil, Colombia, Ecuador, Guatemala, Nicaragua, Paraguay, Uruguay and Venezuela) transformed their planning agency through a rule of law issued by the President (Decree, Decree Law, Presidential Agreement, Provisional Measure, etc.), while the remaining six countries (Bolivia, Chile, Costa Rica, Dominican Republic, Panama and Peru) changed their planning body trough Law. Once again, in these latter countries, it was the President who initiated the legislation, submitting the respective bill to Congress.

Further evidence, presented in table 3, from Argentina, Chile, Colombia and Ecuador show that Presidents in these countries extensively used their decree power to restructure the planning agencies: in Argentina, Presidents restructured the planning body eight times; in Chile, Presidents did so five times; in Colombia, this frequency was up to 15 times; and in Ecuador, Presidents changed the planning body six times. These modifications prompted by the Presidents gradually reshaped the planning agencies by altering its organizational structure, adding and/or withdrawing functions and relocating the position and hierarchy of the agency vis-a-vis other public agencies.

Latin American Presidents have also been bestowed by constitution with the power to nominate, appoint and dismiss government officials, including the head of the planning organization. "In Latin America, it is common for each incoming President 
Table 2 Legal instruments used to transform the planning offices

\begin{tabular}{|c|c|c|c|}
\hline Country & Planning body & Rule of law & Year \\
\hline Argentina & Ministerio de Planificación & Decree 27 & 2003 \\
\hline Bolivia & Ministerio de Planificación & Law $N^{\circ} 3351$ & 2006 \\
\hline Brazil & Ministerio do planejamento, & Exec. Measure No. 1911-8 & 1999 \\
\hline Chile & MIDEPLAN & Law $N^{\circ} 18.899$ & 1990 \\
\hline Colombia & Depart. Nacional de Planeación & Decree 1832 & 2012 \\
\hline Costa Rica & MIDEPLAN & Law No. 5525 & 1973 \\
\hline D. Republic & Secr. de Estado de Planificación & Law No. 496 & 2006 \\
\hline Ecuador & Secr. Nac. de Planificación & Exec. Decree No. 1372 & 2004 \\
\hline Guatemala & SEGEPLAN & Gov. agreement 224 & 2003 \\
\hline Nicaragua & CONPES & Executive Decree 113 & 2007 \\
\hline Panama & Ministerio de Planificación & Law 97 & 1998 \\
\hline Paraguay & Secretaria Técnica de Planificación & Decree $N^{\circ} 4.070$ & 2004 \\
\hline Peru & Centro Nac. de Planeamiento & Law 28522 & 2009 \\
\hline Uruguay & Ofic. Planeamiento y Presupuesto & Decree 91 & 1997 \\
\hline Venezuela & Ministerio de Planific. y Finanzas & Presid. Decree N ${ }^{\circ} 7.187$ & 2010 \\
\hline
\end{tabular}

Source: constructed by the author, 2014

to change not only the people in charge of the ministries but also the overall structure of government by creating new ministries, eliminating others, changing their names, functions, and scope, and the like" (Scartascini 2008: 38).

\section{The Role of Compliance in the Changing Character of the Central Planning Agencies}

Chun and Rainey define goal ambiguity as "the extent to which an organizational goal or set of goals allows leeway for interpretation" (Chun and Rainey 2005: 3). An organizational goal loses clear significance and becomes vague when it invites a

Table 3 Amendments to the planning agencies made by presidential mandate

Country Presidential mandates

Argentina Decree 7.290, 1961; Law 16.964, 1966; Decree 1.057, 1973; Law 21.431,1977; Law 21.909, 1978; Law of Ministries, 1983; Law of Ministries 26.338, 2003; Decree No 1283, 2003

Chile $\quad$ Law N $N^{\circ} 16.635,1967$; Decree $N^{\circ} 303$, 1971; Decree 966, 1975; Law N ${ }^{\circ}$ 18.989, 1990

Colombia Law 19,1958; Decree 0239, 1959; Decree- law 3242, 1963; Decree 2996, 1968; Decree 983, 1972; Decree 294, 1973; Decree law 627, 1974; Law 38 of 1989; Decree 2410, 1989; Decree 2167, 1992; Decree 1363, July 2000; Decree 160, 2002; Decree 195, 2004; Decree 4355, 2005 Decree 3517, 2009

Ecuador Emergency Decree Law 19, 1954; Executive Decree 120, 1998; Executive Decree 1372, 2004; Executive Decree 103, 2007 
number of different interpretations (DiMaggio 1987; Feldman 1989; Locke et al. 1989; Epstein and O’Halloran 1999; Kelemen 2000; Huber and Shipan 2002).

By the mid-1960s, all Latin American countries had a permanent organization inside the machinery of the central government responsible for planning activities. Although central planning agencies structurally evolved in diverse ways in different countries, their goals and procedures nonetheless manifested prominent similarities. Planning bodies were in charge of (i) advising the executive in preparing National Development Plans based upon macro-economic analysis and econometric models; (ii) assisting the President on economic matters; (iii) coordinating development activities of line ministries and administrative agencies; and (iv) executing studies on the national economy. It was not unusual for mandates and functions to be broad.

Almost all these goals were unclear because people could have many possible ways of interpreting words such as economic strategy, national productivity, development plans and development policy, depending on their political and economic standpoint. Moreover, even if people should agree on the meaning of one goal, they could still disagree on the specific way of attaining it (Wilson 1989). By the mid-1960s, Waterston (1966) observed that this situation contributed to the central planning agencies being called to do tasks that were unrelated to planning. "For example, the Venezuelan central planning agency initiated a program for establishing seven automotive assembly plants, and carried out the program over a 2-year period before turning it over to a ministry" (Waterston 1966: 421).

The leeway for interpretation of the central planning agency's organizational goals has not significantly changed since Waterston's research was published. One approach to assess the extent of ambiguity in the mission statements of the Latin American central planning agencies is the Gunning Fog index (GFI), an indicator for evaluating the degree of blurriness in a written passage. In this sense, the GFI predicts the extent to which a piece of writing can be easily understood by readers. Some previous research has used this index as an indicator of mission statement clarity. For example, Weiss and Piderit (1999) applied the GFI to the mission statements of 304 public schools in order to assess the impact of mission clarity on school performance. Later, in their effort to evaluate the extent of ambiguity in the goals of the American Federal Administrative agencies, Chun and Rainey (2005) utilized the GFI in combination with other three indicators: directive goal ambiguity, evaluative goal ambiguity and priority goal ambiguity. Specifically, through the GFI, Chun and Rainey measured the mission's comprehension ambiguity.

The GFI captures average sentence length and the frequency of use of multisyllabic words ${ }^{2}$ : the higher the GFI, the harder the written passage is to comprehend. While near-universal understanding requires an index of less than 8 for texts in English, in Spanish it calls for an index no greater than 20. As illustrated in Fig. 1 the GFI was applied to the current mission of ten Latin American planning organizations attaining an average score of 36.2. These rather high scores suggest that the mission statement of

\footnotetext{
${ }^{2}$ The Gunning Fog Index was originally constructed by Robert Gunning in 1952. The algorithm starts by determining the average sentence length, before introducing a count of complex words and subsequently averaging the sentence length with the percentage of complex words by use of the following formula: $0.4\left[\left(\frac{\text { words }}{\text { Sentences }}\right)+100\left(\frac{\text { Complex }}{\text { Words }}\right)\right]$
} 


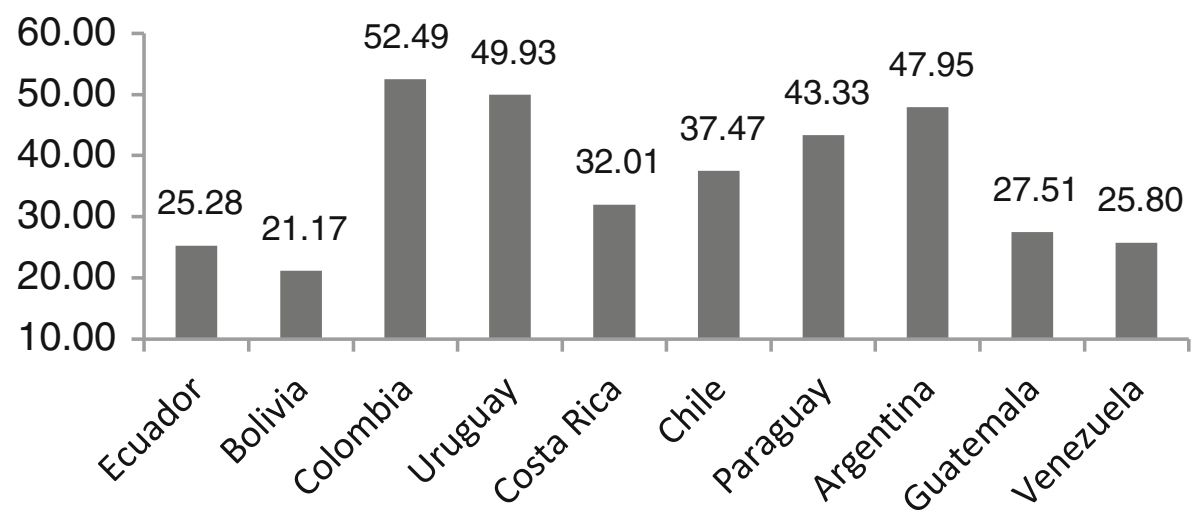

Fig. 1 Fog Index applied to the mission of the planning office. Source: Constructed by the author, 2014

the planning agencies is complicated and hard to communicate, thus allowing for great possibility of interpretation in terms of what the agency is expected to do.

However, aware that the GFI is not free of subjectivity and that Jung (2013) stated that the GFI of an agency's mission statement did not have any statistically expected effect on various empirical studies, this research complements the GFI with the work inspired by Huber and Shipan (2002) on Deliberate Discretion. The authors explore how elected officials use statutes to establish policy details in an effort to achieve desired outcomes. In this context, the scholars pay attention to two different strategies: one is to write long statutes with extremely detailed language in an effort to micromanage the policy making process; while the other is to write vague statutes that leave many details unspecified, thereby delegating policy making authority to bureaucrats (Huber and Shipan 2002).

Based on Huber and Shipan, this research quantifies the lack of precision in the planning agencies' current functions as the percentage of functions that fall under a general policy language, as opposed to specific policy language. Specific tasks are understood here as those that entail the agency doing something concrete and measurable, such as formulating the national development plan, preparing the annual investment budget and establishing the evaluation criteria for the national development plan, while general policy language entails broad functions such as coordinating decentralization policies, advising the President on economic matters, conducting sectoral and macroeconomic studies, participating in the definition of economic policy, etc. Table 4 provides examples of general and specific policy language for some of the functions of the planning agencies from four countries.

Table 5 codes the above mentioned percentage for the planning functions of eleven planning agencies of Latin America. With the exception of Guatemala, which presents a $38 \%$ of general policy language, more than $50 \%$ of the functions of the central planning agencies consistently fall under a general policy language across all other countries analyzed, the upper case being Peru, with $78 \%$. 
Table 4 Examples of general and specific policy language

Argentina (Decree 27/ 2003)

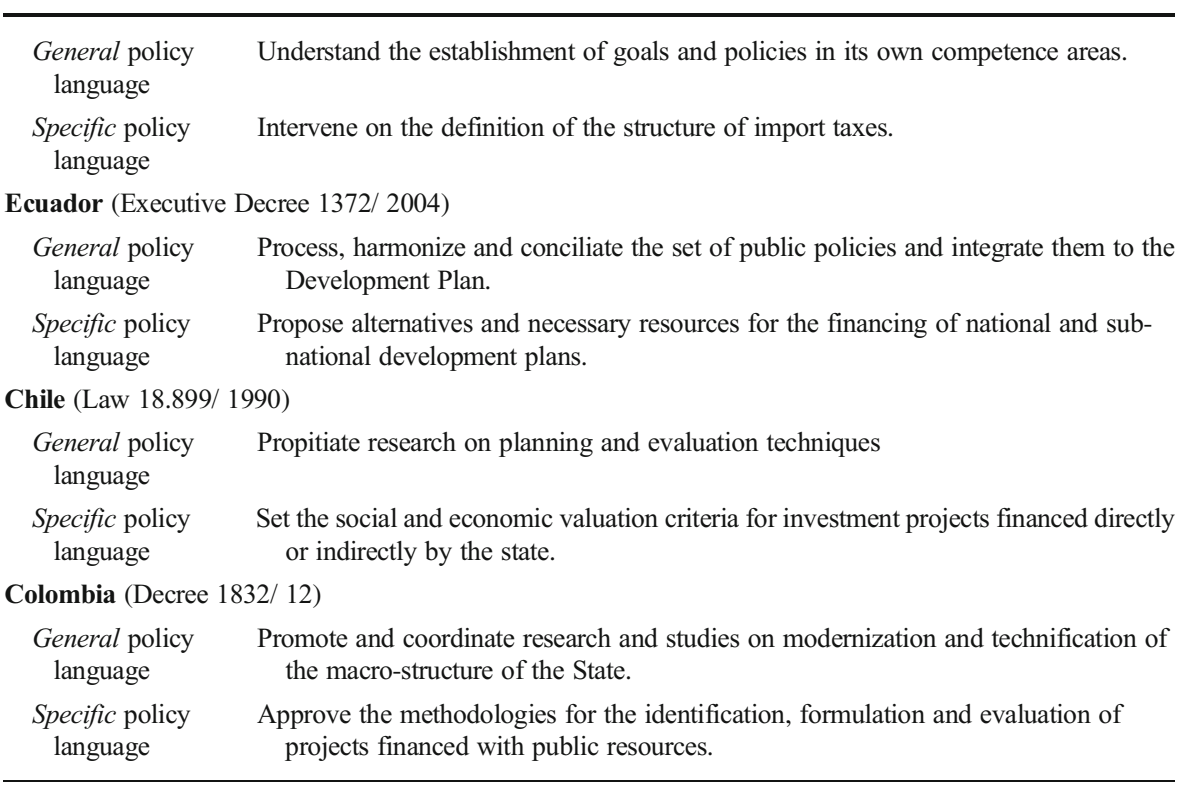

Source: Constructed by the author, 2014

\section{Conversion Mode of Organizational Change}

Latin-American presidents have played a major role in shaping the structure of public administration in their countries. Either through executive action (executive orders or

Table 5 Percentage of functions that fall under general or specific policy language

\begin{tabular}{lllllll}
\hline & \multicolumn{2}{l}{ General Policy Language } & & \multicolumn{2}{l}{ Specific Policy Language } & \multirow{2}{*}{ Total Functions } \\
\cline { 2 - 3 } & No. & $\%$ & & No. & $\%$ & \\
\hline Argetina & 29 & $54 \%$ & & 25 & $46 \%$ & 54 \\
Bolivia & 9 & $64 \%$ & & 5 & $36 \%$ & 14 \\
Brasil & 8 & $73 \%$ & & 3 & $27 \%$ & 11 \\
Colombia & 18 & $55 \%$ & & 15 & $45 \%$ & 33 \\
Costa Rica & 2 & $50 \%$ & & 2 & $50 \%$ & 4 \\
Ecuador & 12 & $60 \%$ & & 8 & $40 \%$ & 20 \\
Chile & 7 & $70 \%$ & & 3 & $30 \%$ & 10 \\
Guatemala & 5 & $38 \%$ & & 8 & $62 \%$ & 13 \\
Paraguay & 11 & $65 \%$ & & 6 & $35 \%$ & 17 \\
Perú & 7 & $78 \%$ & & 2 & $22 \%$ & 9 \\
Venezuela & 13 & $54 \%$ & & 11 & $46 \%$ & 24 \\
\hline
\end{tabular}

Source: Constructed by the author, 2014 
reorganization plans) or by delegated faculties, Presidents have influenced the structure of the state's public bureaus, including the central planning organizations, by creating, transforming or dismantling administrative agencies as well as rearranging functions within bureaucracy. Much of this influence comes from the presidential power to veto legislation and the executive right to introduce legislative proposals in certain policy areas, particularly in the creation of new bureaucratic offices. This authority of creating, transforming and terminating administrative agencies has not faced effective veto points. There have not been strong actors with access to institutional or extrainstitutional means of blocking the presidential will of organizational change. This situation, combined with the fact that the legal mandates and functions of the central planning agencies leave many details unspecified, has allowed the executive substantial discretion in transforming the structural arrangement of the planning agency. Through the redeployment of the goals, functions and purposes of the planning organization, the planning agencies have been converted in ways unanticipated by their designers. Historically, Presidents in Latin America have adopted a wait-and-see approach that better suited their interests, becoming the main agent of endogenous organizational change within this process.

However, what is the rationale for Presidents to influence the course of action taken by the planning agencies? In this respect, it is important to refer back to Thelen's remark in terms that actors driving change may or may not have transformational motives or, in other words, that transformations may not respond to an explicit or intentional motivation. While Presidents have been the main actor responsible for the evolving role of the central planning agencies, they have not always actively sought to preserve or change the planning agency. Instead, they act in an opportunistic manner and depending on the circumstances and historical moments they use the planning agency in ways that better suit their interests. In this process, Presidents have either prompted transformations of the planning agency or contributed toward the agency's isolation and organizational inertia.

The research finds that the planning agencies have been useful to the President in at least four aspects:

(i) Mobilizing foreign aid resources: Presidents first saw the opportunity in establishing planning agencies when the Alliance for Progress and later on the International Bank for Reconstruction and Development-IBRD (World Bank) started requiring countries to set up a planning agency and construct a national development plan, as conditionality to access external aid and obtain technical assistance.

By the late-1960s, Presidents had fulfilled their commitment made in Punta del Este, the central planning agency was in motion and at least one national development plan had been created. However, these plans were infrequently used as a basis for economic policy making and appeared to constitute a diplomatic maneuver for attracting foreign capital

(ii) Exercising veto against politically powerful ministers and controlling the spending appetite of the line ministers: Starting in the late-1970s and throughout the 1980 s, countries in the region created mechanisms inside the planning agency to filter and prioritize the spending proposals coming from the line ministries. By means of these project prioritization tools, governments could rationalize the national budget and provide technical viability to public investment projects. This 
meant that all ministries and other public organizations had to submit their investment projects to the planning office for approval prior to sending them to the Ministry of Finance.

(iii) Providing the President with technical justifications and legitimacy: Supported by the work conducted in the planning agencies, Presidents have sought to remain popular and strengthen their legitimacy by using national plans to explain how national goals and economic growth can be achieved. Also, Presidents have used the technocracies inside the planning agencies to justify politically costly decisions such as fiscal adjustments, budget cuts and tax rises. Finally in countries under military dictatorships, like Argentina, the country's security and economic growth was defended under a technocratic parlance.

(iv) Providing Presidents with accurate information and control: Common to the origin of all planning agencies was the recruitment of qualified staff, the creation of systems and quantitative tools for policy analysis, aspects that were voluntarily financed by the international organizations that needed an agency that could "do things right". Over the years, a stock of information and data was accumulated and consolidated in these agencies, more so than in any other agency, thus becoming a valuable resource for the President's office to design their priority policies. While turnover of staff at the planning agency occurred, the data was jealously kept.

Likewise, the tentacles of the planning agency across the public sector have historically granted Presidents with an across-the-board control-point and influence of the public sector, whether through the establishment of satellite planning dependencies inside line ministries, regional and municipal planning offices or through the appointment of the head of the planning agency in the boards of other public agencies.

\section{Conclusions}

This paper explains the paradoxical transformation of the central planning agencies in Latin America. Although these agencies were the natural candidates for retrenchment when confronted with pro-market and multilevel planning public sector reforms, they nonetheless persisted with distinct structural attributes from one country to another. Even though external shocks and pressures have been powerful stimuli for changes in organizational arrangements of the planning bodies, transformations occurred neither rapidly nor as a result of exogenous distresses. Transformations have been the result of 60 years of gradual redeployment by presidents of the goals, functions and purposes of planning organizations.

Indeed, Presidents have been major agents of change underpinning transformations of central planning agencies. The political environment in Latin America, particularly presidential systems of government that have characterized the region, have granted presidents with powers to rearrange the functions and the internal structure of the public sector via decrees, laws, and reorganization plans with little or close to zero veto powers from other stakeholders, such as Congress. However, presidents are actors who have ambiguous preferences about the organizational continuity of organizations. They have not actively sought to preserve planning agencies nor have they tried to 
change them. Instead, presidents have exploited whatever possibilities exist within the institutional context of planning organizations to achieve their ends. In this sense, presidents, acting in an "opportunistic" way, adopt a wait-and-see approach while pursuing conversion of the agency to one that better suits their interests. When planning agencies seem futile or do not match the President's agenda, the organization undergoes intermittent periods of ostracism, transforming into a marginal actor within the public sector hierarchy.

Open Access This article is distributed under the terms of the Creative Commons Attribution 4.0 International License (http://creativecommons.org/licenses/by/4.0/), which permits unrestricted use, distribution, and reproduction in any medium, provided you give appropriate credit to the original author(s) and the source, provide a link to the Creative Commons license, and indicate if changes were made.

\section{References}

Bonvecchi, A., \& Carlos, S. (2011). The presidency and the executive branch in Latin America: What we know and what we need to know. In Research department publications 4756. Washington: InterAmerican Development Bank, Research Department.

Cameron, M. A. (2009). Latin America's left turns: beyond good and bad. Third World Quarterly, 30(2), 331348.

Chun, Y. H., \& Rainey, H. (2005). Goal ambiguity in U.S. Federal agencies. Journal of Public Administration Research and Theory, 15(1), 1-30.

DiMaggio, P. (1987). Nonprofit organizations in the production and distribution of culture. In: The nonprofit sector: Research handbook, ed. W. Powell. New Haven: Yale University Press.

Epstein, D., \& O’Halloran, S. (1999). Delegating powers. A transaction costs politics approach to policy making under separate powers. Cambridge: Cambridge University press.

Feldman, M. (1989). Order without design: information production and policy making. Stanford: Stanford University Press.

García Bossio, H. (2008). Génesis del Estado Desarrollista Latinoamericano: el Pensamiento y la Praxis Política de Helio Jaguaribe (Brasil) y de Rogelio Frigerio (Argentina). Buenos Aires: Pontificia Universidad Católica- Departamento de Economía, Documento de Trabajo No 23.

Huber, J., \& Shipan, C. R. (2002). Deliberate discretion? The institutional foundations of bureaucratic autonomy. Cambridge: Cambridge University Press.

Iglesias, E. (2006). El papel del Estado y los paradigmas económicos en América Latina. In: Revista de la CEPAL, 90

ILPES. (2013). Aportes a la reflexión sobre las actividades del ILPES: antecedentes sobre el financiamiento y la gestión de los recursos. Brasilia: XIV Reunión del Consejo Regional de Planificación del ILPES.

Jung, C. S. (2013). Organizational goal ambiguity and job satisfaction in the public sector. Journal of Public Administration Research and Theory. doi:10.1093/jopart/mut020.

Kelemen, M. (2000). Too much or too little ambiguity: the language of total quality management. Journal of Management Studies, 37, 483-498.

Leiva Lavalle, J. (2010). Instituciones e Instrumentos para el planeamiento gubernamental en América Latina. Brasilia: Instituto de Investigación Económica Aplicada-CEPAL.

Locke, E. A., Chah, D., Harrison, S., \& Lustgarten, N. (1989). Separating the effects of goal specificity from goal level. Organizational Behavior and Human Decision Processes, 43, 270-287.

Mahoney, J., \& Thelen, K. (2010). A theory of gradual institutional change. In Explaining institutional change. Ambiguity, agency, and power. Cambridge: Cambridge University Press.

Mainwaring, S. (1990). Presidentialism in Latin America. Latin America Research Review, 25(1), 157-179.

Mainwaring, S., \& Shugart, M. (1997). Presidentialism and democracy in Latin America: Rethinking the terms of the debate. In Presidentialism and democracy in Latin America. Cambridge: Cambridge University Press.

Primo Braga, C. (2006). Import Substitution Industrialization in Latin America: Experience and Lessons for the Future. Paper prepared for a seminar in honor of Professor Werner Baer, held at the University of Illinois at Urbana-Champaign, December 1-2 
Rius, A. and Van de Walle, N. (2003). Political institutions and economic policy reform. A paper presented at the GDN Workshop on Understanding Reform in Cairo on January, 16-17.

Scartascini, C. (2008). Who's who in the PMP: An overview of actors, incentives, and the roles they play. In Policy making in Latin America. How politics shapes policies. Washington: Inter-American Development Bank.

Sondrol, P. (2005). The presidential tradition in Latin America. International Journal of Public Administration, 28, 517-530.

Streeck, W., \& Thelen, K. (2005). Introduction: Institutional change in advance political economies. In: beyond continuity: institutional change in advance political economies. Oxford: Oxford University Press.

Taffet, J. (2007). Foreign aid as foreign policy. The alliance for progress in Latin America. New York: Taylor \& Francis Group.

Thelen, K. (1999). Historical institutionalism in comparative politics. Annual Review of Political Science, 2, 369-404.

Thelen, K. (2003). How institutions evolve. Insights from comparative historical analysis. In Comparative historical analysis in the social sciences. Cambridge: Cambridge University Press.

Thelen, K. (2009). Institutional change in advanced political economies. British Journal of Industrial Relations, 47, 3.

Tsebelis, G. (2002). Veto players: How political institutions work. Princeton: Princeton University Press.

Tsebelis, G., \& Aleman, E. (2005). Presidential conditional agenda setting in Latin America. World Politics, 57(3), 396-420.

Waterston, A. (1966). Development planning. Lessons of experience. London: Oxford University Press.

Weiss, J., \& Piderit, S. (1999). The value of mission statements in public agencies. Journal of Public Administration Research and Theory, 9, 193-224.

Wilson, J. Q. (1989). Bureaucracy: What government agencies do and why they do it. New York: Basic Books.

Luis Bernardo Mejia Guinand is an anthropologist and political scientist at Universidad de los Andes (Bogotá). He has an MA in public policy from the University of New York and a $\mathrm{PhD}$ in public policy from the University of Maastricht (Netherlands). Currently he serves as assistant professor of political science at the University of the Andes. 